\title{
PENYULUHAN PEMANFAATAN PEKARANGAN DENGAN TANAMAN OBAT KELUARGA DIMASA PANDEMI DI DESA BAKARAN BATU KECAMATAN BATANG KUIS KABUPATEN DELI SERDANG
}

\author{
Erlita Chaniago $^{1 *}$, Aisyah lubis ${ }^{2}$, Dermawan Hutagaol ${ }^{3}$, Farida Hariani ${ }^{4}$, Nurma Ani ${ }^{5}$ \\ 1,2,3,4,5 Agroteknologi, Fakultas Pertanian, Universitas Al AzharJl Pintu Air IV No. 214 Kwala Bekala \\ Padang Bulan Medan, 20142 \\ *erlitaaidil@gmail.com
}

\begin{abstract}
ABSTRAK. Dimasa pandemi saat ini umumnya masyarakat enggan untuk berobat ke Rumah Sakit, dengan berbagai macam alasan. Tanaman obat keluarga (TOGA) menjadi salah satu pilihan masyarakat untuk ditanam di lahan pekarangan, dengan pertimbangan karena dapat dimanfaatkan untuk kesehatan. Tanaman obat dapat dijadikan obat yang aman, tidak mengandung bahan kimia, murah, dan mudah didapat.Gaya hidup kembali ke alam, saat ini semakin meningkat, seiring dengan kesadaran masyararakat terhadap bahaya yang ditimbulkan oleh bahan bahan kimia, baik yang terkandung dalam makanan ataupun obat-obatan. Dampak dari itu penggunaan obat-obat tradisional sudah kembali membudaya di Indonesia.Indonesi sangat kaya akan keanekaragaman hayati, diantaranya berupa ratusan jenis tumbuhan/tanaman obat. Tumbuhan tersebut banyak dimanfaatkan selain untuk penyembuhan dan pencegahan penyakit, juga untuk peningkatan daya tahan tubuh, serta pengembalian kesegaran yang pada akhirnya meningkatkan kesehatan masyarakat.Jenis tanaman obat, pada umumnya lebih banyak tumbuh sebagai tanaman liar, akan tetapi pada saat ini tanaman obat banyak ditanam di kebun dan dilahan pekarangan. Oleh karena itu bibit tanaman obat banyak dibutuhkan oleh masyarakat untuk ditanam di lahan pekarangan.Tujuan dari pengabdian masyarakat ini adalah memberikan penyuluhan kepada masyarakat tentang pemanfatan pekarangan dengan tanaman obat keluarga (TOGA) . Metode yang diberikan adalah dengan cara penyuluhan ,diskusi dan bermusyawarah tentang pemanfaatan pekarangan dengan tanaman obat keluarga. Dan kesimpulanya masyarakat paham bagaimana memanfaatkan pekarangan dengan menanam tanaman obat-obatan
\end{abstract}

Kata kunci: pandemi, tanaman obat keluarga, obat tradisional

ABSTRACT. During the current pandemic, people are generally reluctant to go to the hospital for treatment, for various reasons. Family medicinal plants (TOGA) are one of the people's choices to be planted in their yards, with the consideration that they can be used for health. Medicinal plants can be used as medicines that are safe, do not contain chemicals, are cheap, and easy to obtain. The lifestyle of returning to nature is currently increasing, along with public awareness of the dangers posed by chemicals, whether contained in food or medicine. -medicine. The impact of this is that the use of traditional medicines has re-established itself in Indonesia. Indonesia is very rich in biodiversity, including hundreds of types of plants/medicinal plants. These plants are widely used in addition to healing and preventing disease, as well as to increase endurance, and restore freshness which in turn improves public health. Types of medicinal plants, in general, are mostly grown as wild plants, but at this time many medicinal plants are planted in the garden and in the yard. Therefore, many medicinal plant seeds are needed by the community to be planted in their yards. The purpose of this community service is to provide counseling to the community about the use of home gardens with family medicinal plants (TOGA). The method given is by way of counseling, discussion and deliberation about the use of the yard with family medicinal plants. And the conclusion is that people understand how to take advantage of the yard by planting medicinal plants

Keywords: pandemic, family medicinal plants, traditional medicine

Terima 5 Januari 2022 Terima dan di revisi 7 Januari 2022 Disetujui 12 Januari 2022

\section{PENDAHULUAN}

Tanaman Obat Keluarga (TOGA) pada hakekatnya adalah tanaman berkhasiat yang ditanam di lahan pekarangan dan dikelola oleh keluarga. Jenis tanaman toga ditanam untuk memenuhi keperluan keluarga akan obatobatan tradisional yang dapat dibuat sendiri. 
Tanaman obat keluarga (TOGA) menjadi salah satu pilihan masyarakat untuk ditanam di lahan pekarangan, dengan pertimbangan karena dapat dimanfaatkan untuk kesehatan. Tanaman obat dapat dijadikan obat yang aman, tidak mengandung bahan kimia, murah, dan mudah didapat. Gaya hidup kembali ke alam, saat ini semakin meningkat, seiring dengan kesadaran masyararakat terhadap bahaya yang ditimbulkan oleh bahan bahan kimia, baik yang terkandung dalam makanan ataupun obat-obatan. Dampak dari itu penggunaan obat-obat tradisional sudah kembali membudaya di Indonesia.

Indonesi sangat kaya akan keanekaragaman hayati, diantaranya berupa ratusan jenis tumbuhan/tanaman obat. Tumbuhan tersebut banyak dimanfaatkan selain untuk penyembuhan dan pencegahan penyakit, juga untuk peningkatan daya tahan tubuh, serta pengembalian kesegaran yang pada akhirnya meningkatkan kesehatan masyarakat.

Salah satu fungsi Toga adalah sebagai sarana untuk mendekatkan tanaman obat kepada upaya-upaya kesehatan masyarakat yang antara lain meliputi:

1. Upaya preventif (pencegahan)

2. Upaya promotif (meningkatkan/ menjaga kesehatan)

3. Upaya kuratif (penyembuhan penyakit) (Susi Mindarti dan Bebet Nurbaeti, 2015)

Pada umumnya, tanaman obat lebih banyak tumbuh sebagai tanaman liar. Akan tetapi, kini tanaman obat banyak ditanam di kebun dan di lahan pekarangan. Tak sedikit masyarakat memanfaatkannya sebagai tanaman toga.

Memanfaatkan jenis tanaman toga merupakan upaya pencegahan terhadap penyakit. Selain itu, jenis tanaman toga juga dapat dijadikan usaha promotif atau meningkatkan kesehatan, hingga upaya kuratif sebagai penyembuh penyakit (Ibrahim Hasan, 2021) Dengan membudidayakan tanaman obat sendiri di rumah, tentu akan mendatangkan banyak manfaat bagi keluarga. Sebagian besar tanaman obat berkhasiat untuk mengobati berbagai macam penyakit dan juga bermanfaat bagi kesehatan. Tanaman obat sendiri memiliki beberapa jenis dan masing-masing jenis memiliki khasiatnya sendiri. Oleh karena itu, semakin banyak menanam berbagai jenis tanaman obat, maka semakin banyak pula manfaat yang bisa didapatkan.
Kita bisa memulai budidaya tanaman obat dengan memilih jenis tanaman yang juga bisa digunakan sebagai bumbu dapur. Misalnya lengkuas, jahe, kencur, kunyit, dan rempahrempah yang lain.

Tanaman obat tersebut tergolong mudah dalam proses budidayanya. Selain itu, kita juga bisa menanam tanaman obat yang juga bisa memberikan kesan estetik pada lahan. Misalnya, lavender, kumis kucing, bunga kenop, dan lainnya (Nandy,2021)

Kecenderungan meningkatnya penggunaan obat tradisional didasari oleh beberapa faktor, yaitu:

1. Pada umumnya, harga obat-obatan buatan pabrik yang sangat mahal, sehingga masyarakat mencari alternatif pengobatan yang lebih murah.

2. Efek samping yang ditimbulkan oleh obat tradisional sangat kecil dibandingkan dengan obat buatan pabrik.

3. Kandungan unsur kimia yang terkandung di dalam obat tradisional sebenarnya menjadi dasar pengobatan kedokteran modern. Artinya, pembuatan obat-obatan pabrik menggunakan rumus kimia yang telah disentetis dari kandungan bahan alami ramuan tradisional.

Beberapa manfaat dari menanam tanaman TOGA yaitu :

1. Sebagai obat alami untuk keluarga : Dengan tanaman yang ditanam sendiri, kita bisa mengobati aneka ragam penyakit. Mulai dari penyakit ringan seperti panas dan flu, hingga penyakit berat seperti jantung dan asam urat.

2. Memperindah rumah : Jika ingin memiliki tampilan pekarangan yang alami dan berbeda dengan tanaman hias pada umumnya, maka tanaman obat bisa menjadi pilihan yang tepat.

3. Peluang binis : Mengingat tingginya kebutuhan tanaman obat baik dalam konsumsi pribadi maupun umum, maka kita dapat memanfaatkan hal ini menjadi bisnis jual beli tanamn obat dengan prospek yang menjanjikan.

4. Bahan campuran jamu tradisional : Beberapa jenis tanaman TOGA dapat dimanfaatkan sebagai bahan campuran jamu antara lain temu lawak, brotowali dan jinten hitam.

5. Bahan makanan sehari-hari : Kemangi, daun seledri, daun pepaya, blutru, jahe, bawang, dan sebagainya merupakan 
contoh jenis tanaman TOGA yang bisa diolah menjadi makanan sehari-hari(Berita Desa, 2020)

\section{Perawatan tanaman obat}

Tanaman yang dipelihara di pekarangan rumah tidak memerlukan perawatan khusus, baik sebagai bumbu dapur atau bahan obat. Perlakuan khusus dalam budi daya tanaman obat dilakukan dalam skala usaha, dengan tujuan untuk memperoleh kualitas dan kuantitas hasil yang optimum. Kegiatan pemupukan dan pengandalian hama penyakit tanaman perlu dilakukan. Kegiatan ini sangat erat hubungannya dengan penggunaan bahan kimiawi yang terkandung dalam pupuk atau pestisida. Pemakaian bahan kimiawi dapat mencemari lingkungan, baik tanah maupun air, dan yang paling berbahaya residu yang dihasilkan akan terakumulasi dalam produk tanaman yang dihasilkan. Untuk itu, perlu diperkenalkan sistem budi daya yang tidak tergantung pada bahan-bahan kimia. Sistem ini dikenal dengan istilah pertanian organik. Dalam budi daya tanaman obat dapat dimanfaatkan pupuk organik untuk menambah unsur hara mineral yang dibutuhkan tanaman. Pupuk organik yang digunakan di antaranya adalah pupuk kandang, bokhasi, kompos, humus, sampah dapur, dan serasah daun. Selain itu, sebagai bahan pengendali hama penyakit tanaman, dapat dimanfaatkan pestisida alami yang terdapat di sekitar rumah, seperti tanaman babadotan (Ageratum conyzoides), sirsak, lantana, dan daun tembakau.

\section{METODE}

Berdasarkan permasalahan yang dihadapi dalam hubunganya dengan program yang akan dilakukan untuk menyelesaikan permasalahnan tersebut, maka metode pendekatan yang dilakukan antara lain:

Pendidikan Masyarakat

Kegiatan ini dilakukan dengan memberikan penyuluhan kepada masyarakat dalam bidang pertanian khususnya pentingnya pengetahuan tentang tanaman obat keluarga atau apotik hidup yang sekarang sudah berkurang pembudidayaanya. Kegiatan ini juga mendengarkan pandangan masyarakat tentang tanaman obat keluarga yang sangat bermanfaat pada masa pandemi sekarang sebagai alternatif dari pengobatan kimia. Dari hasil penyuluhan dan diskusi bersama terlihat bagaimana bersemangatnya masyarakat untuk menumbuhkan kembali akan manfaat dari tanaman obat keluarga ini bagi kesehatan.

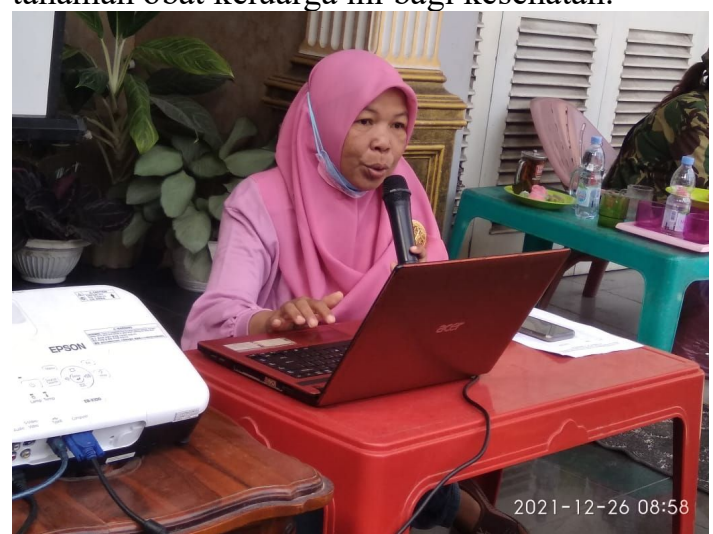

Gambar 1 Penyuluhan yang disampaikan oleh Erlita, SP.,MP salah satu staf pengajar di Fakultas Pertanian Universitas Al Azhar

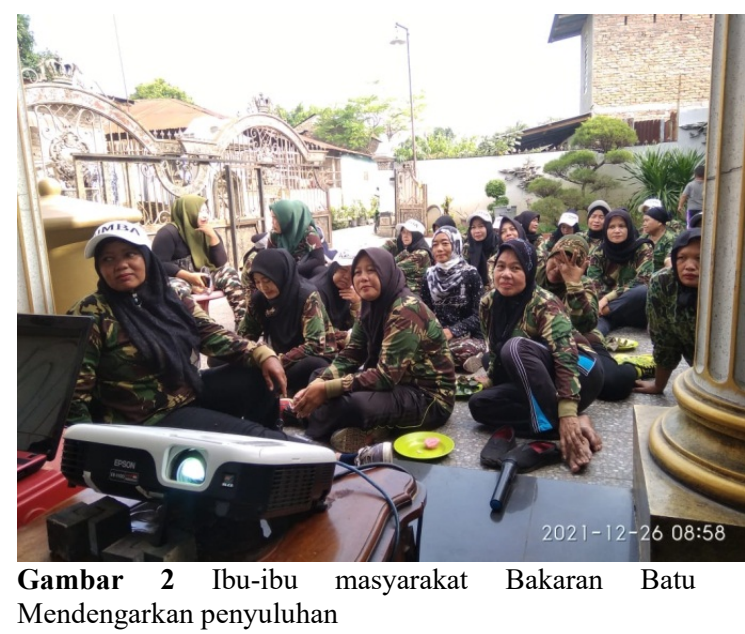

\section{HASIL DAN PEMBAHASAN}

Sesuai dengan metode pelaksanaan kegiatan pengabdian kepada masyarakat telah dilakukan kegiatan ceramah dan diskusi serta penyuluhan tentang pemanfaatan perkarangan dengan tanaman obat keluarga di masa pandemi. Ada beberapa hasil yang kita peroleh dari penyuluhan pemanfaatan pekarangan dengan tanaman obat keluarga dimasa pandemi yaitu:

1. Masyarakat dapat memahami manfaat dan khasiat dari tanaman obat keluarga sebagai pengganti obat-obatan yang berasal dari bahan kimia

2. Masyarakat juga memahami tanaman obat keluarga ini selain dapat dijadikan sebagai obat herbal juga dapat dijadikan bumbu dapur 
3. Menumbuhkan kembali minat masyarakat untuk membudidayakan tanaman obat keluarga yang sudah lama tidak dikembangkan.

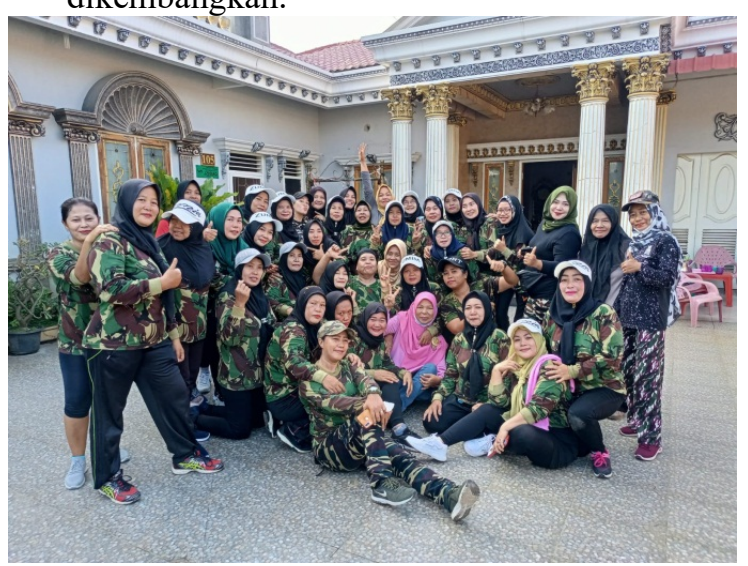

Gambar 3 Foto bersama ibu-ibu Bakaran Batu Maju setelah selesai acara penyuluhan

\section{SIMPULAN}

Dari pelaksanaan penyuluhan ini dapat disimpulkan bahwa masyarakat mulai memahami manfaat dari pekarangan yang ditanami tanaman obat-obatan sebagai alternatif pengobatan kimia

\section{UCAPAN TERIMAKASIH}

Dengan selesaikan pengabdian terhadap masyarakat ini di ucapkan banyak terima kasih kepada Ibu ibu kecamatan Batang kuis, Kabupaten Deli Serdang

\section{DAFTAR PUSTAKA}

Berita Desa. 2020. Manfaat Tanaman Obat Keluarga (TOGA). http://kalirejokulonprogo.desa.id/index.php/artikel/202 0/6/7/manfaat-tanaman-obat-keluargatoga

Ibrahim Hasan, 2021. 12 Jenis Tanaman Toga, Lengkap dengan Manfaatnya BagiKesehatan. https://www.merdeka.com/jateng/12jenis-tanaman-toga-lengkap-denganmanfaatnya-bagi-kesehatan-kln.html

Nandy. 2021. https://www.gramedia.com/bestseller/tanaman-obat-keluarga/

Susi Mindarti dan Bebet Nurbaeti, 2015. Balai Pengkajian Teknologi Pertanian (BPTP) Jawa Barat 